\title{
PENGEMBANGAN PERANGKAT PEMBELAJARAN MATEMATIKA MATERI BANGUN DATAR SEGIEMPAT BERBASIS METODE PENEMUAN TERBIMBING (GUIDED DISCOVERY) UNTUK PESERTA DIDIK KELAS VII SMP/MTS
}

\section{DEVELOPMENT OF LEARNING MATHEMATICS MATERIALS AT SIXTH BASED ON GUIDED DISCOVERY METHOD FOR STUDENTS IN CLASS VII SMP/MTS}

\author{
Muh. Qardawi Hamzah'), Andi Halimah'), Baharuddin ${ }^{3)}$ \\ 1,2,3)Fakultas Tarbiyah dan Keguruan Universitas Islam Negeri Alauddin Makassar \\ qardawihamzah@gmail.com ${ }^{1}$, andi.halimah@uin-alauddin.ac.id²), $\underline{\text { baharuddin.abbas@uin- }}$ \\ alauddin.ac.id $\left.{ }^{3}\right)$
}

\begin{abstract}
Abstrak
Penelitian ini bertujuan untuk mengembangkan perangkat pembelajaran matematika materi bangun datar segiempat berbasis metode penemuan terbimbing yang valid, praktis, dan efektif. Jenis penelitian yang digunakan adalah Research \& Development (Penelitian dan Pengembangan) dengan mengacu pada model 4D yaitu: define, design, develop, dan disseminate. Produk yang dikembangkan berupa RPP, buku ajar siswa dan LKPD yang berbasis metode penemuan terbimbing pada materi bangun datar segiempat. Instrumen yang digunakan dalam penelitian ini adalah lembar validasi, lembar pengamatan keterlaksanaan perangkat pembelajaran, lembar pengamatan pengelolaan pembelajaran, lembar pengamatan aktivitas peserta didik, lembar angket respons peserta didik dan guru serta tes hasil belajar. Berdasarkan hasil uji coba yang dilakukan, diperoleh bahwa (1) Hasil validasi perangkat pembelajaran yaitu RPP dan LKPD berada pada kategori valid dan buku ajar siswa berada pada kategori valid, (2) Praktis berdasarkan hasil pengamatan keterlaksanaan perangkat pembelajaran berada pada kategori terlaksana seluruhnya, respons guru terhadap buku ajar siswa adalah 100\% dan LKPD memberikan respons 90\%; sedangkan analisis data respons peserta didik terhadap buku ajar siswa terdapat $99,5 \%$ siswa yang memberi respons positif, dan $82,5 \%$ siswa yang memberi respons positif pada LKPD, (3) Efektif berdasarkan pengelolaan pembelajaran diperoleh berada pada kategori sangat baik, aktivitas peserta didik dalam kategori sangat baik, dan tes hasil belajar berada dalam kategori tinggi dengan skor rata-rata tes adalah 12 dari skor ideal 15. Disimpulkan bahwa pada tahap uji coba yang dilaksanakan pengembangan perangkat pembelajaran matematika materi bangun datar segiempat berbasis metode penemuan terbimbing kelas VII SMP/MTs telah memenuhi kriteria valid, praktis dan efektif.
\end{abstract}

Kata Kunci: perangkat pembelajaran, bangun datar segiempat, metode penemuan terbimbing

\begin{abstract}
The objective of this research is to develop a mathematics learning tool for rectangular flat structure material based on valid, practical, and effective guided discovery methods. The type of this research used is Research \& Development by referring to the 4D model, namely: define, design, develop, and disseminate. The product developed is in the form of lesson plans, student textbooks and LKPD which are based on guided discovery methods on rectangular flat material. The instruments used in this study were validation sheets, observation sheets of learning device implementation, learning management observation sheets, student activity observation sheets, student and teacher response questionnaire sheets and learning achievement test. Based on the results of the trials conducted, it was found that (1) the
\end{abstract}


results of the validation of learning tools namely RPP and LKPD were in the valid category, while the student textbook was in the valid category; (2) practically, based on observations of the implementation of learning devices in the overall implementation category, the teacher's response to student textbooks is $100 \%$ and LKPD gives a response of $90 \%$; while the analysis of students' response data to student textbooks there were $99.5 \%$ of students who gave positive responses, and 82,5\% of students who gave positive responses to LKPD. Effectively based on the management of learning obtained are in the very good category, student activity in the excellent category, and tests learning outcomes are in the high category with an average test score of 12 from an ideal score of 15 . It can be concluded that at the trial stage the development of the quadrilateral flat mathematics learning tool based on the guided discovery method of grade VII SMP/MTs met the valid, practical, and effective criteria.

Keywords: learning development, quadrilateral, guided discovery method

How to Cite: Hamzah, M.Q., Halimah, A., \& Baharuddin (2019). Pengembangan perangkat pembelajaran matematika materi bangun datar segiempat berbasis metode penemuan terbimbing (guided discovery) untuk peserta didik kelas VII SMP/MTs. Al-Asma: Journal of Islamic Education, 1(2), 148-160.

\section{PENDAHULUAN}

Komponen terpenting dari sistem pendidikan adalah kurikulum, karena kurikulum merupakan komponen pendidikan yang dijadikan acuan oleh setiap lembaga pendidikan, baik oleh pengelola maupun penyelenggara, khususnya oleh kepala sekolah dan guru. Kurikulum sebagai program belajar, mengandung: tujuan, isi program, dan strategi/cara melaksanakan program. Pembelajaran adalah operasional dari kurikulum. Melalui kegiatan pembelajaran, kurikulum mempunyai kekuatan mempengaruhi pribadi peserta didik. Guru mempunyai tugas ganda, yakni harus menguasai kurikulum dan menerjemahkan serta menjabarkan kepada peserta didik melalui proses pembelajaran. Harus dicegah terjadinya kesenjangan antara kurikulum sebagai program dan pembelajaran operasionalisasi program. Menurut Gredler belajar adalah proses orang memperoleh berbagai kecakapan, keterampilan, dan sikap (Sahabuddin, 2007: 80). Belajar adalah suatu aktivitas yang dilakukan seseorang dengan sengaja dalam keadaan sadar untuk memperoleh suatu konsep, pemahaman, atau pengetahuan baru sehingga memungkinkan seseorang terjadinya perubahan perilaku yang relatif tetap baik dalam berpikir, merasa, maupun dalam bertindak (Susanto, 2013: 4). Pembelajaran akan berhasil apabila didahului oleh penyusunan rencana pelaksanaan pembelajaran yang bersumber dari silabus. Oleh karena itu, guru dituntut agar terampil menyusun rencana pelaksanaan pembelajaran dan mampu membelajarkannya kepada peserta didik di dalam kelas.

Perangkat pembelajaran merupakan salah satu faktor yang memegang peranan penting dalam kegiatan pembelajaran. Perangkat pembelajaran adalah sekumpulan sumber atau alat belajar yang memungkinkan peserta didik dan guru melakukan kegiatan pembelajaran. Perangkat pembelajaran akan memengaruhi keberhasilan proses pembelajaran di kelas karena memberikan kemudahan dan dapat membantu guru dalam mempersiapkan dan melaksanakan kegiatan pembelajaran. Oleh sebab itu, perangkat pembelajaran mutlak diperlukan oleh seorang guru dalam melaksanakan pembelajaran (Abidin, 2014: 292). 
Kurikulum tentu mempunyai kekuatan atau potensi dalam memengaruhi pribadi peserta didik jika diterjemahkan dan ditransformasikan oleh guru kepada peserta didik. Namun, jika tidak ditransformasikan oleh guru, kurikulum tidak mempunyai kekuatan apa-apa, bahkan merupakan suatu benda mati yang tidak ada gunanya. Oleh sebab itu, kurikulum dan guru harus merupakan satu kesatuan yang tidak terpisahkan. Artinya, kurikulum harus ada dalam pikiran guru. Sehubungan dengan itu, maka guru harus; 1) menguasai kurikulum, artinya guru harus mempelajari kurikulum. Guru harus menguasai tujuan kurikulum, isi program (pokok bahasan/sub pokok bahasan) yang harus diberikan kepada peserta didik, pada kelas dan semester mana pokok bahasan itu dibelajarkan, dan bagaimana ia harus membelajarkannya; 2) menguasai isi dari setiap pokok bahasan/sub pokok bahasan dengan cara mempelajari buku pelajaran (text book) yang berkenaan dengan pokok bahasan tersebut; 3) mampu menerjemahkan dan menjabarkan silabus tersebut menjadi suatu program yang lebih operasioal, sehingga ia siap mentransformasikannya kepada peserta didik. Penjabaran ini dilakukan melalui suatu penyusunan program pembelajaran atau rencana pelaksanaan pembelajaran.

Guru diharapkan memiliki keterampilan menyusun perencanaan atau persiapan pembelajaran yang bersumber dari silabus. Jika guru tidak mempelajari silabus dan tidak menggunakannya ketika menyusun rencana pelaksanaan pembelajaran (RPP), maka apa yang diberikan guru kepada peserta didik tidak sesuai dengan standard isi. Hal berarti bahwa pembelajaran yang dilakukan guru di sekolah dapat menyimpang dari kurikulum yang sudah ditentukan (berlaku).

Belajar dan pembelajaran sebagai suatu proses, sudah tentu harus dapat mengembangkan dan menjawab beberapa persoalan yang mendasar, mengenai: 1) kemana proses tersebut akan diarahkan? 2) apa yang harus dibahas dalam proses belajar dan pembelajaran? 3) bagaimana cara melakukannya? 4) bagaimana mengetahui berhasil tidaknya proses tersebut? Dari uaraian-uraian permasalahan tersebut maka dapat diketahui persoalan pertama berhubungan dengan 'tujuan proses pembelajaran', persoalan kedua berbicara tentang 'materi atau bahan pembelajaran', persoalan ketiga berhubungan dengan 'metode dan perangkat yang digunakan dalam proses pembelajaran', persoalan keempat berkenaan dengan 'penilaian dalam proses pembelajaran'. Keempat persoalan (tujuan, bahan, metode dan perangkat, serta penilaian) ini menjadi komponen utama yang harus dipenuhi dalam proses pembelajaran. Keempat komponen tersebut tidak berdiri sendiri, tetapi saling berhubungan dan saling memengaruhi satu sama lain (terintegrasi).

Pada saat proses belajar-mengajar berlangsung di kelas, akan terjadi hubungan timbal balik antara guru dan peserta didik yang beraneka ragam, dan itu akan mengakibatkan terbatasnya waktu guru untuk mengontrol bagaimana pengaruh tingkah lakunya terhadap motivasi belajar peserta didik. Selama pelajaran berlangsung guru sulit menentukan tingkah laku mana yang berpengaruh positif terhadap motivasi belajar peserta didik, misalnya gaya mengajar mana yang memberi kesan positif pada diri peserta didik selama ini, strategi mana yang dapat membantu kejelasan konsep selama ini, metode dan model pembelajaran mana yang tepat untuk dipakai dalam menyajikan suatu pembelajaran sehingga dapat membantu mengaktifkan peserta didik dalam belajar.

Berdasarkan hasil observasi yang telah dilakukan di MTs Madani Alauddin PaoPao kelas VII melalui wawancara dengan bapak Amiruddin Mansur sebagai guru mata 
pelajaran matematika diperoleh informasi bahwa perangkat pembelajaran pada sekolah tersebut masih tergolong belum memadai, dilihat dari RPP yang digunakan dari tahun ke tahun tidak ada perubahan karena menggunakan RPP yang dibeli atau diunduh sehingga RPP yang digunakan terkadang tidak sesuai dengan apa yang dibutuhkan oleh peserta didik. Dalam proses pembelajaran yang dilakukan di kelas masih berpusat pada guru (teacher centered) dengan menggunakan metode ceramah. Hal ini terbukti karena guru belum melakukan suatu pengelolaan kegiatan belajar-mengajar yang melibatkan peserta didik secara aktif, sehingga proses pembelajaran terkadang membosankan dan kurang efektif. Selain itu, buku ajar siswa yang digunakan tidak memberikan tantangan kepada siswa untuk menentukan sifat, defenisi dan rumus. Buku masih bersifat pinjaman dari perpustakaan sekolah sehingga tidak semua peserta didik memiliki buku serta beberapa peserta didik menganggap bahwa materi yang ada pada buku masih sulit untuk mereka pahami. Pada proses pembelajaran LKPD masih sangat sedikit digunakan dan hanya memuat soal-soal tertentu. LKPD tidak memuat kegiatan yang melibatkan siswa untuk menentukan sifat dan defenisi serta menemukan rumus tertentu. Lembar Kerja Peserta Didik (LKPD) adalah lembaran-lembaran berisi tugas yang harus dikerjakan oleh peserta didik. Lembar kegiatan ini biasanya berupa petunjuk dan langkah-langkah untuk menyelesaikan suatu tugas (Aisfar, 2009: 20)

Hal tersebut memperkuat anggapan bahwa guru dituntut untuk lebih kreatif dalam proses belajar-mengajar, sehingga tercipta suasana belajar yang menyenangkan pada diri peserta didik yang pada akhirnya meningkatkan motivasi belajar peserta didik. Salah satu alternatif untuk memperbaiki kondisi pembelajaran yang dipaparkan di atas adalah metode pembelajaran yang tepat bagi peserta didik serta dapat memecahkan masalah yang dihadapi. Proses pembelajaran selain diawali dengan perencanaan yang bijak, serta didukung dengan komunikasi yang baik, juga harus didukung dengan pengembangan perangkat pembelajaran yang mampu membelajarkan peserta didik. Pengembangan tersebut diperlukan agar menghasilkan output yang berkualitas dan mempunyai kompetensi utuh, seperti yang diharapkan dalam kurikulum.

Salah satu metode pembelajaran yang mendukung pelaksanaan Kurikulum 2013 adalah metode penemuan terbimbing (guided discovery). Metode penemuan terbimbing (guided discovery) mempunyai prinsip yang sama dengan inkuiri dan Problem Solving yang merupakan metode standar proses pembelajaran dalam peraturan Menteri Pendidikan dan kebudayaan nomor 65 tahun 2013. Tidak ada perbedaan yang prinsipil pada ketiga istilah ini, pada guided discovery lebih menekankan pada ditemukannya konsep atau prinsip yang sebelumnya tidak diketahui. Pada guided discovery juga masalah yang diperhadapkan kepada peserta didik semacam masalah yang direkayasa oleh guru (Kementerian Pendidikan dan Kebudayaan, Guided Discovery, 2013).

Metode penemuan terbimbing merupakan metode yang dianggap cukup efektif dalam proses pembelajaran matematika untuk mengaktifkan peserta didik guna mencapai hasil pembelajaran yang maksimal. Hal ini sesuai dengan teori konstruktivisme yang menyatakan bahwa peserta didik harus menemukan sendiri dan mentransformasikan informasi kompleks, mengecek informasi baru dengan aturan-aturan lama dan merevisinya apabila aturan-aturan itu tidak sesuai lagi (Trianto, 2010: 28)

Dalam guided discovery guru memberikan kesempatan peserta didiknya untuk menjadi seorang problem solver, seorang scientis, historin, atau ahli matematika. Bahan 
ajar tidak disajikan dalam bentuk akhir, tetapi peserta didik di tuntut untuk melakukan berbagai kegiatan menghimpun informasi, membandingkan, mengkategorikan, menganalisis, mengintegrasikan, mereorganisasikan bahan serta membuat kesimpulankesimpulan. Guru berperan sebagai pembimbing dengan memberikan kesempatan kepada peserta didik untuk belajar secara aktif, sebagaimana pendapat guru harus dapat membimbing dan mengarahkan kegiatan belajar peserta didik sesuai dengan tujuan. Kondisi seperti ini ingin merubah kegiatan belajar mengajar yang teacher oriented menjadi student oriented (Kementerian Pendidikan dan Kebudayaan, Guided Discovery, 2013).

Metode penemuan terbimbing sebagai suatu metode mengajar yang bermanfaat untuk pembelajaran matematika. Sund berpendapat bahwa discovery (penemuan terbimbing) adalah proses mental dimana peserta didik mengasimilasikan suatu konsep atau suatu prinsip (Subroto, 2002: 70). Di dalam metode ini peserta didik didorong untuk berpikir sendiri sehingga dapat menemukan prinsip umum, berdasarkan bahan yang difasilitasi oleh guru. Sampai seberapa jauh peserta didik dibimbing, tergantung pada kemampuannya dan pada materi yang dipelajari (Setiawan, 2010: 32).

\section{METODE PENELITIAN}

Jenis penelitian yang digunakan adalah penelitian dan pengembangan atau Research and Development (R\&D). Research and Development adalah metode penelitian yang digunakan untuk menghasilkan produk tertentu, dan menguji keefektifan produk tersebut.

Penelitian ini merupakan penelitian pengembangan yang mengacu pada model pengembangan 4D. Penelitian ini menggunakan model pengembangan 4D karena tahapan yang ada pada model ini sangat cocok dalam penelitian dan pengembangan perangkat pembelajaran yang akan dilakukan oleh peneliti. Menurut Thiagarajan dalam Trianto, model pengembangan 4D terdiri atas 4 tahap utama, yaitu: (define) pendefinisian, (design) perancangan, (develop) pengembangan, dan (disseminate) penyebaran.

Subjek uji coba dalam penelitian ini adalah siswa kelas VII D MTs Madani Alauddin Pao-Pao. Instrumen pengumpulan data yang digunakan dalam penelitian ini adalah lembar validasi ahli, lembar observasi keterlaksanaan perangkat pembelajaran, lembar observasi pengelolaan pembelajaran, lembar observasi aktivitas peserta didik, angket respons guru, dan, peserta didik, serta, tes hasil belajar

\section{HASIL DAN PEMBAHASAN}

Pengembangan perangkat pembelajaran matematika berbasis pendekatan kontekstual telah dilaksanakan dengan model pengembangan 4D yang terdiri dari 4 tahap yaitu Define (Pendefinisian), Design (Perancangan), Develop (Pengembangan), dan Disseminate (Penyebaran). Tetapi tahapan Disseminate (Penyebaran) tidak terlaksana secara sempurna karena keterbatasan waktu dan biaya, sehingga hanya disosialisasikan ke guru matematika lainnya untuk digunakan di kelas lain. Penjelasan tahap-tahap pengembangan tersebut dijelaskan lebih lanjut sebagai berikut: 


\section{Tahap Pendefinisian (Define)}

Penelitian ini dilakukan pada kelas VII MTs Madani Alauddin Pao-Pao pelajaran 2019/2020, materi pembelajaran adalah bangun datar segiempat. Kelas yang dijadikan subjek penelitian adalah kelas VII D yang terdiri dari 40 orang.

\section{a. Analisis Awal-Akhir}

Pada tahap ini dianalisis untuk mengidentifikasi masalah-masalah yang dihadapi oleh peserta didik dan guru dalam pembelajaran matematika. Berdasarkan hasil observasi yang telah dilakukan maka, diperoleh informasi bahwa perangkat pembelajaran pada sekolah tersebut masih tergolong belum memadai, dilihat dari RPP yang digunakan dari tahun ke tahun tidak ada perubahan karena beberapa guru matematika menggunakan RPP yang dibeli, buku ajar siswa yang digunakan masih bersifat buku pinjaman dari perpustakaan sekolah sehingga tidak semua peserta didik memiliki buku dan pada proses pembelajaran LKPD masih sangat sedikit digunakan.

Atas dasar permasalahan di atas, maka pada penelitian akan dikembangkan perangkat pembelajaran matematika berupa RPP, buku ajar siswa dan LKPD yang berbasis metode penemuan terbimbing yang kemudian akan digunakan dalam proses pembelajaran. Dengan harapan bahwa pengembangan perangkat pembelajaran ini dapat menjadi sumber belajar bagi peserta didik sehingga aktif dalam proses pembelajaran berlangsung dan menjadi sumber referensi bagi guru setiap tahun pada mata pelajaran matematika materi bangun datar segiempat.

\section{b. Analisis Peserta Didik}

Analisis peserta didik dilakukan untuk mengetahui karakteristik peserta didik yang akan disesuaikan dengan rancangan dan pengembangan perangkat pembelajaran. Berikut ini penjelasan karakteristik peserta didik:

1) Daya serap yang dimiliki setiap peserta didik berbeda-beda

2) Latar belakang pendidikan orang tua setiap peserta didik berbeda-beda

3) Lingkungan tempat tinggal setiap peserta didik berbeda-beda.

Berdasarkan karakteristik peserta didik di atas yang heterogen, maka kelas VII D yang menjadi sampel penelitian

\section{c. Analisis Materi}

Dari hasil observasi peneliti terkait analisis materi, diperoleh bahwa ketersediaan buku ajar matematika sebagai pegangan peserta didik masih terbatas. Sehingga materimateri yang disajikan guru sama saja dengan materi yang ada pada buku ajar matematika pegangan peserta didik yang langsung menyajikan konsep secara umum tanpa mengaitkan materi dengan hal-hal baru.

\section{d. Analisis Tugas}

Berdasarkan hasil observasi yang telah dilakukan, diperoleh informasi bahwa tugas-tugas yang diberikan oleh guru terhadap peserta didik belum mampu menempatkan kenyataan dan pengalaman baru peserta didik sebagai titik awal pembelajaran.

\section{e. Spesifikasi Tujuan Pembelajaran}

Tujuan pembelajaran ini disusun berdasarkan kompetensi dasar sebagaimana yang tercantum dalam Kurikulum 2013. Tujuan pembelajaran yang dihasilkan mampu memberikan pemahaman dan pengalaman baru pada peserta didik. 


\section{Tahap Perancangan (Design)}

Tahapan berikutnya yaitu tahap perancangan, pada tahap perancangan peneliti mulai merancang perangkat pembelajaran matematika berbasis metode penemuan terbimbing pada pokok bahasan bangun datar segiempat kelas VII. Pada tahap ini, dirancang desain dan sistematika perangkat pembelajaran yang akan digunakan dalam pembelajaran.

\section{a. Penyusunan Tes Hasil Belajar}

Dalam menyususn tes hasil belajar terlebih dahulu dimulai dengan penyusunan kisi-kisi tes. Kisi-kisi tes merupakan suatu acuan atau petunjuk yang harus diikuti saat penyusunan THB. Kisi-kisi THB disusun berdasarkan spesifikasi tujuan pembelajaran, yang di dalamnya merupakan sebuah peta penyebaran butir pertanyaan yang sudah dipersiapkan sedemikian sehingga dengan butir pertanyaan tersebut dapat ditentukan dengan tepat tingkat ketercapaian penguasaan materi seorang peserta didik berdasarkan spesifikasi tujuan pembelajaran, divalidasi oleh ahli, dan diujicobakan. Tes hasil belajar dihasilkan dalam penelitian ini berupa tes hasil belajar matematika pada pokok bahasan bangun datar segiempat..

\section{b. Pemilihan Media}

Media yang digunakan pada penelitian ini adalah kertas berpetak dan penggaris. Selain itu, peneliti juga memilih media dengan cara menggunakan media yang tersedia saat proses pembelajaran yang berkaitan dengan materi yang diajarkan. Pada penelitian ini media pembelajaran yang dibutuhkan adalah: papan tulis, spidol, penghapus, dan lainlain yang berkaitan dengan materi.

\section{c. Pemilihan Format}

Format perangkat pembelajaran (RPP, Buku ajar siswa, dan LKPD) yang digunakan hanya berisi satu materi pembelajaran yaitu bangun datar segiempat dengan menggunakan metode penemuan terbimbing. Format perangkat pembelajaran tersebut disesuaikan dengan rancangan pembelajaran tahun 2013 yang meliputi kompetensi inti, kompetensi dasar, indikator, materi pembelajaran, pendekatan/model/metode pembelajaran, media/alat/sumber pembelajaran, langkah-langkah pembelajaran, dan penilaian.

\section{d. Perancangan Awal Perangkat Pembelajaran}

1) Hasil rancangan Rencana Pelaksanaan Pembelajaran

Format RPP yang dikembangkan dalam rancangan RPP ini, yaitu: kompetensi inti adalah tingkat kemampuan untuk mencapai standar kompetensi lulusan yang harus dimiliki peserta didik pada setiap tingkatan/kelas. Kompetensi dasar adalah kemampuan untuk mencapai kompetensi inti yang harus dimiliki oleh peserta didik melalui pembelajaran. Indikator pencapaian kompetensi adalah perilaku yang dapat diukur dan diobservasi untuk menunjukkan ketercapaian kompetensi dasar tertentu yang menjadi acuan penilaian mata pelajaran. Tujuan pembelajaran adalah aspek yang akan dicapai setiap pertemuan berdasarkan kompetensi dasar dan indikator yang telah ditetapkan. Materi pembelajaran berisi materi inti bangun datar segiempat. Pendekatan, model dan metode pembelajaran berfungsi sebagai patokan pembelajaran dengan menggunakan metode penemuan terbimbing. Media memuat keterangan sumber media, bahan atau alat yang digunakan dalam pembelajaran yaitu buku ajar siswa berbasis metode penemuan terbimbing pada materi bangun datar segiempat. Langkah-langkah kegiatan pembelajaran 
berisi uraian rancangan proses kegiatan pembelajaran yang akan dilakukan berdasarkan karakteristik materi dan komponen pembelajaran metode penemuan terbimbing. Penilaian mencakup jenis dan bentuk penilaian yang digunakan untuk mengevaluasi hasil pembelajaran.

2) Hasil rancangan Buku ajar siswa

Buku ajar siswa rancangan berdasarkan kurikulum matematika yang berlaku sesuai dengan jenjang pendidikan yaitu SMP/MTs.

3) Hasil rancangan Lembar Kerja Peserta Didik

Lembar Kegiatan Peserta Didik yang berhasil dirancang pada tahap ini sebanyak 3 buah sesuai dengan banyaknya RPP. LKPD dirancang dalam bentuk tugas-tugas yang dikerjakan secara berkelompok. LKPD ini, siswa diharapkan dapat menyelesaikan masalah yang berkaitan dengan bangun datar segiempat dan diselesaikan sendiri oleh peserta didik.

\section{Tahap Pengembangan (Develop)}

Pada tahap pengembangan ini bertujuan untuk menghasilkan perangkaat pembelajaran matematika berbasis metode penemuan terbimbing yang telah direvisi sehingga layak digunakan dalam penelitian atau diujicobakan. Kegiatan yang dilakukan pada tahap ini adalah: validasi ahli dan uji coba.

\section{a. Hasil Validasi Ahli}

Pada tahap ini, dilakukan validasi perangkat pembelajaran dan intrumen yang telah dibuat melalui pertimbangan para ahli (validator) untuk menentukan layak tidaknya produk perangkat pembelajaran matematika berbasis metode penemuan terbimbing untuk digunakan. Perangkat-perangkat yang dimaksud adalah Rencana Pelaksanaan Pembelajaran, Buku ajar siswa, dan Lembar Kegiatan Peserta Didik. Sementara instrumen yang dimaksud di sini adalah lembar validasi pengamatan keterlaksanaan pembelajaran, lembar validasi pengamatan pengelolaan pembelajaran, lembar validasi pengamatan aktivitas peserta didik, lembar validasi respons guru dan peserta didik, serta lembar validasi tes hasil belajar. Penilaian para ahli dilakukan dengan memberi tanda centang pada aspek yang sesuai dan dilengkapi catatan-catatan kecil pada bagian yang perlu diperbaiki beserta saran-sarannya.

1) Revisi Perangkat Pembelajaran

a) Validasi Tahap Pertama

Proses validasi yang pertama kali dilakukan dengan mengajukan rancangan awal (Prototype $I$ ) perangkat pembelajaran menggunakan metode penemuan terbimbing pada materi bangun datar segiempat yang telah dikembangkan pada bagian awal kepada validator. Kemudian perangkat tersebut diperiksa dan diberi beberapa masukan. Deskripsi masukan yang diberikan oleh validator sebagai berikut:

Tabel 1. Saran untuk Perbaikan Prototype I oleh Validator

\begin{tabular}{ll}
\hline Aspek & Saran Perbaikan \\
\hline RPP & $\begin{array}{l}\text { 1. Sesuaikan Kompetensi Dasar, Indikator Pencapaian dengan } \\
\text { langkah kegiatan }\end{array}$ \\
& $\begin{array}{l}\text { 2. Revisi langkah inti pembelajaran dengan mengaitkan pada } \\
\text { prinsip/komponen penemuan terbimbing }\end{array}$ \\
3. Penulisan agar diperbaiki
\end{tabular}




\begin{tabular}{cl}
\hline Buku ajar siswa & 1. Desain isi buku harus menarik \\
& 2. Sistematika materi harus teratur \\
& 3. Susunan subbab materi harus sistematis \\
& 4. Jumlah soal latihan ditambah \\
\hline LKPD & 1. Sesuaikan tujuan pembelajaran yang ada di LKPD dan di RPP \\
& 2. Perhatikan waktu penyelesaian LKPD \\
\hline
\end{tabular}

b) Validasi Tahap Kedua

Proses validasi tahap kedua dilakukan dengan mengajukan hasil revisi (Prototype II) sesuai dengan saran perbaikan yang diberikan pada proses validasi tahap pertama dari tim validator. Kemudian hasil revisi (Prototype II) diperiksa dan diberi beberapa masukan. Deskripsi masukan yang diberikan oleh validator sebagai berikut:

Tabel 2. Saran untuk Perbaikan Prototype II oleh Validator

\begin{tabular}{|c|c|}
\hline Aspek & Saran Perbaikan \\
\hline RPP & $\begin{array}{l}\text { 1. Langkah kegiatan harus lebih jelas yang dilakukan guru dan } \\
\text { peserta didik } \\
\text { 2. Jumlah RPP sesuaikan dengan subab pada buku ajar } \\
\text { 3. Perhatikan kembali lembar penilaian yang digunakan }\end{array}$ \\
\hline Buku ajar siswa & $\begin{array}{l}\text { 1. Tambahkan sumber buku internasional } \\
\text { 2. Upayakan setiap soal harus memiliki gambar } \\
\text { 3. Pengembangan soal-soal menantang masih perlu } \\
\text { dipermantap }\end{array}$ \\
\hline LKPD & $\begin{array}{l}\text { Harus lebih dikembangkan lagi tahapannya sesuai dengan metode } \\
\text { yang digunakan }\end{array}$ \\
\hline
\end{tabular}

c) Validasi Tahap Ketiga

Proses validasi tahap ketiga dilakukan dengan mengajukan hasil revisi (Prototype III) sesuai dengan saran perbaikan yang diberikan pada proses validasi dari tahap pertama dari tim validator. Kemudian hasil revisi (Prototype III) diperiksa.

Dari validasi tahap ketiga ini, tim validasi telah memberikan penilaian terhadap perangkat pembelajaran matematika berbasis metode penemuan terbimbing pada pokok bahasan bangun datar segiempat yang telah dikembangkan melalui lembar validasi.

2) Hasil Validasi

a) Hasil Uji Validasi Rencana Pelaksanaan Pembelajaran

Hasil penilaian terhadap RPP berbasis penemuan terbimbing pada materi bangun datar segiempat yang diberikan oleh kedua validator dapat disimpulkan bahwa rata-rata penilaian atau hasil validasi dari para ahli menyatakan bahwa rata-rata aspek RPP berbasis penemuan terbimbing pada materi bangun datar segiempat adalah 3,1. Hal ini berarti bahwa hasil penilaian dari kedua validator "valid" dengan kategori validitas berada pada interval $2.5 \leq M<3.5$

b) Hasil Uji Validasi Buku Ajar Siswa

Hasil penilaian terhadap buku ajar siswa berbasis penemuan terbimbing pada materi bangun datar segiempat yang diberikan oleh kedua validator dapat disimpulkan bahwa rata-rata penilaian atau hasil validasi dari para ahli menyatakan bahwa rata-rata 
aspek buku ajar siswa berbasis penemuan terbimbing pada materi bangun datar segiempat adalah 3,3. Hal ini berarti bahwa hasil penilaian dari kedua validator "valid" dengan kategori validitas berada pada interval 2,5 $\leq M<3,5$

c) Hasil Uji Validasi Lembar Kerja Peserta Didik

Hasil penilaian terhadap LKPD berbasis penemuan terbimbing pada materi bangun datar segiempat yang diberikan oleh kedua validator dapat disimpulkan bahwa rata-rata penilaian atau hasil validasi dari para ahli menyatakan bahwa rata-rata aspek LKPD berbasis penemuan terbimbing pada materi bangun datar segiempat adalah 3,1. Hal ini berarti bahwa hasil penilaian dari kedua validator "valid" dengan kategori validitas berada pada interval 2,5 $\leq M<3,5$

d) Hasil Uji Validasi Lembar Pengamatan Pengelolaan Pembelajaran

Hasil penilaian terhadap lembar pengamatan pengelolaan pembelajaran berbasis penemuan terbimbing pada materi bangun datar segiempat yang diberikan oleh kedua validator dapat disimpulkan bahwa rata-rata penilaian atau hasil validasi dari para ahli menyatakan bahwa rata-rata aspek lembar pengamatan pengelolaan pembelajaran matematika berbasis penemuan terbimbing pada materi bangun datar segiempat adalah 3,26. Hal ini berarti bahwa hasil penilaian dari kedua validator "valid" dengan kategori validitas berada pada interval 2,5 $\leq M<3,5$

e) Hasil Uji Validasi Lembar Pengamatan Keterlaksanaan Perangkat Pembelajaran

Hasil penilaian terhadap lembar pengamatan keterlaksanaan perangkat pembelajaran berbasis penemuan terbimbing pada materi bangun datar segiempat yang diberikan oleh kedua validator dapat disimpulkan bahwa rata-rata penilaian atau hasil validasi dari para ahli menyatakan bahwa rata-rata aspek lembar pengamatan keterlaksanaan perangkat pembelajaran berbasis penemuan terbimbing pada materi bangun datar segiempat adalah 3,3. Hal ini berarti bahwa hasil penilaian dari kedua validator "valid" dengan kategori validitas berada pada interval 2,5 $\leq M<3,5$.

f) Hasil Uji Validasi Lembar Pengamatan Aktivitas Peserta Didik dalam Pembelajaran

Hasil penilaian terhadap lembar pengamatan aktivitas peserta didik dalam proses pembelajaran berbasis penemuan terbimbing pada materi bangun datar segiempat yang diberikan oleh kedua validator dapat disimpulkan bahwa rata-rata penilaian atau hasil validasi dari para ahli menyatakan bahwa rata-rata aspek lembar pengamatan aktivitas peserta didik dalam pembelajaran berbasis penemuan terbimbing pada materi bangun datar segiempat adalah 3.2. Hal ini berarti bahwa hasil penilaian dari kedua validator "valid" dengan kategori validitas berada pada interval 2,5 $\leq M<3,5$

g) Hasil Uji Validasi Lembar Angket Respons Peserta Didik

Hasil penilaian terhadap lembar angket respons peserta didik berbasis penemuan terbimbing yang diberikan oleh kedua validator dapat disimpulkan bahwa rata-rata penilaian atau hasil validasi dari para ahli menyatakan bahwa rata-rata aspek lembar angket respons peserta didik berbasis penemuan terbimbing adalah 3,26 . Hal ini berarti bahwa hasil penilaian dari kedua validator "valid" dengan kategori validitas berada pada interval 2,5 $\leq M<3,5$

h) Hasil Uji Validasi Lembar Angket Respons Guru

Hasil penilaian terhadap lembar angket respons guru berbasis penemuan terbimbing yang diberikan oleh kedua validator dapat disimpulkan bahwa rata-rata penilaian atau hasil validasi dari para ahli menyatakan bahwa rata-rata aspek lembar 
angket respons guru berbasis penemuan terbimbing adalah 3,16. Hal ini berarti bahwa hasil penilaian dari kedua validator "valid" dengan kategori validitas berada pada interval $2,5 \leq M<3,5$

i) Hasil Uji Validasi Tes Hasil Belajar

Hasil penilaian terhadap tes hasil belajar berbasis penemuan terbimbing pada materi bangun datar segiempat yang diberikan oleh kedua validator dapat disimpulkan bahwa rata-rata penilaian atau hasil validasi dari para ahli menyatakan bahwa rata-rata aspek tes hasil belajar berbasis penemuan terbimbing pada materi bangun datar segiempat adalah 3,3. Hal ini berarti bahwa hasil penilaian dari kedua validator "valid" dengan kategori validitas berada pada interval $2,5 \leq M<3,5$

4. Tahap Penyebaran (Disseminate)

Perangkat pembelajaran yang diperoleh pada tahap akhir pengembangan selanjutnya disebarkan ke dalam skala yang lebih luas misalnya di kelas lain, dan di sekolah lain. Tetapi dalam penelitian ini tahapan penyebaran (dissaminate) tidak terlaksana secara sempurna karena keterbatasan waktu dan biaya, sehingga hanya disosialisasikan ke guru matematika lainnya untuk digunakan di kelas lain atau sekolah lain.

\section{SIMPULAN}

Kesimpulan yang dapat ditarik dari penelitian ini adalah perangkat pembelajaran yang dikembangkan menggunakan model 4-D. Tahap define, dilakukan telaah syarat pengembangan perangkat pembelajaran berbasis metode penemuan terbimbing yang sesuai dengan kebutuhan peserta didik dan analisi kebutuhan yang dilakukan adalah : analisis awal akhir, analisis peserta didik, analisis materi, analisis tugas dan spesifikasi tujuan pembelajaran. Tahap design, dilakukan perancangan perangkat pembelajaran berbasis metode penemuan terbimbing berdasarkan kajian tahap pendefenisian yang menghasilkan prototipe 1 berupa RPP, buku ajar, LKPD dan THB. Tahap develop, dilakukan pengambangan perangkat pembelajaran berbasis metode penemuan terbimbing dengan 2 uji yaitu : validasi ahli untuk prototipe 1 sebanyak 3 kali, hasil validasi pertama dinyatakan belum layak kemudian dilakukan revisi sesuai dengan masukan validator, selanjutnya menghasilkan prototipe 2 yang kemudian dinilai belum layak oleh validator sehingga dilakukan revisi menghasilkan prototipe 3 selanjutnya dinyatakan valid dan layak digunakan, uji joba terbatas dilakukan di kelas VII $I_{D}$ MTs Madani Alauddin Pao-Pao untuk menghasilkan perangkat pembelajaran matematika berbasis penemuan terbimbing pada materi bangun datar segiempat yang valid, praktis dan efektif. Kriteria valid diambil berdasarkan hasil validasi perangkat pembelajaran berupa Rencana Pelaksanaan Pembelajaran adalah 3,1; Lembar Kegiatan Peserta Didik adalah 3,1; dan buku ajar adalah 3,3. Dikategorikan valid karena setiap aspek untuk setiap jenis perangkat berada pada interval $2,5 \leq M<3,5$. Kriteria praktis diambil berdasarkan hasil pengamatan keterlaksanaan perangkat pembelajaran yang menunjukkan rata-rata 1,95 yang berarti berada pada rentang $1,5 \leq M \leq 2$ yang menunjukkan bahwa keterlaksanaan perangkat pembelajaran terlaksanaan seluruhnya; analisis data respons guru terhadap buku ajar siswa dan LKPD menyatakan bahwa guru memberikan respons positif $100 \%$ terhadap buku ajar siswa dan 90\% terhadap LKPD; analisis data respons peserta didik terhadap buku ajar siswa terdapat 99,5\% siswa yang memberi respons positif, dan 82,5\% siswa 
yang memberi respons positif pada LKPD. Kriteria efektif diambil berdasarkan pengelolaan pembelajaran yang dilakukan oleh guru dalam kategori sangat baik yakni 3,74 dengan interval 3,5 $\leq K G<4,5$. Aktivitas peserta didik selama proses pembelajaran dalam kategori sangat baik yakni $84 \%$ dengan interval presentase $80 \leq P \leq 100$. Dan tes hasil belajar berada dalam kategori tinggi dengan presentase $75 \%$ skor berada diatas KKM. Tahap disseminate, tahap penyebaran dalam penelitian ini dilakukan terbatas hanya pada kelas VII .

\section{DAFTAR PUSTAKA}

Abidin, Yunus. (2014). Desain Sistem Pembelajaran dalam Konteks Kurikulum 2013. Bandung: Refika Aditama.

Aisfar, Nur Ikrar. (2009). Pengembangan Perangkat Pembelajaran Berbasis Contextual Teaching and Learning (CTL) untuk Pokok Bahasan Teorema Pythagoras pada Siswa SMP Kelas VIII. Skripsi tidak diterbitkan. Makassar: FMIPA UNM.

Amir. (1999). Pengembangan Paket Pembelajaran Kerajinan Tangan dan Kesenian (KTK) pada Kelas III SD Kalisongo III Kecamatan Dau Kabupaten Malang. Tesis S2 tidak diterbitkan. Malang: PPS IKIP Malang.

Kementerian Pendidikan dan Kebudayaan Republik Indonesia 2014. 2014. Peraturan Menteri Pendidikan dan Kebudayaan Republik Indonesia Nomor 103 Tahun 2014 Tentang Pembelajaran pada Pendidikan Dasar dan Pendidikan Menengah. [Online]. Tersedia: www.dikmen.kemdikbud.go.id/kurikulum2013/. [Januari 2015]

Kementerian Pendidikan dan Kebudayaan Republik Indonesia 2013. Gueded Disscovery.[Online].Tersedia:www.dikmen.kemdikbud.go.id/kurikulum2013/. [Agustus 2015] .

Permendiknas No. 41 Tahun 2007: "RPP dijabarkan dari silabus untuk mengarahkan kegiatan belajar siswa dalam upaya mencapai kompetensi dasar (KD)."

Sahabuddin. 2007. Mengajar dan Belajar. Makassar: Badan Penerbit UNM. Ada

Subroto, Suryo. 2002. Proses Belajar Mengajar di Sekolah. Jakarta: Rineka Cipta.

Susanto, Ahmad. 2013. Teori Belajar Pembelajaran di Sekolah Dasar. Jakarta: Kencana. 
